\title{
Research on Institutional Investors, Free Cash Flow And Idle Funds
}

\author{
Yong Liang ${ }^{1,2, a}$, Shengdao Gan $^{1}$ \\ ${ }^{1}$ Sichuan University, Chengdu, Sichuan Province, China \\ ${ }^{2}$ Sichuan Normal University, Chengdu, Sichuan Province, China \\ a3979840@qq.com
}

Keywords: Institutional Investors; Free Cash Flow; Idle Funds.

\begin{abstract}
Idle funds show the agency costs of free cash flow. From the perspective of "Institutional Shareholder Activism", this paper studies the question of idle funds by analyzing idle funds raised by listed companies in Shanghai and Shenzhen stock markets from the year 2009 to 2014. The empirical results show that free cash flow and idle funds are positively related. Institutional investors can supervise idle funds; but they are more concerned about the use efficiency of idle funds, rather than the question of idle funds. Therefore, under normal circumstances, institutional investors acquiesce to the existence of idle funds in free cash flow.
\end{abstract}

\section{Theoretical Basis and Research Hypotheses}

According to the "Pecking Order Theory of Financing", the cost of equity financing is lower than debt financing. Meanwhile, equity financing is faster, and there"s no excessive restriction on using the funds raised in stock markets. So, most listed companies enter the stock markets through various earning means to get financing. However, some raised funds cannot be put in projects construction as the original plan due to constraints of investment opportunities and risks, together with the effects of projects construction progress. Listed companies direct these funds to other purposes, and transfer them to other projects at will. Thus, the returns of funds are difficult to be achieved. In 2012 and 2013, relevant departments introduced the Regulatory Requirements on Management and Use of Funds Raised by Listed Companies, the Management Methods of Funds Raised by Listed Companies and revised documents. These regulations broadened the using range of idle funds raised by listed companies, and simplified the examination and approval procedures on changing the purposes of idle funds.

According to process modes of raised idle funds collected by Qin Liu (2002) [1], Chinese listed companies" process modes on raised idle funds mainly include "depositing in the bank", "trust management", "investing national bonds", "purchasing shares from other companies" and "lending to large shareholders or related parties". Jin Liu et. al (2008) found that, the smaller of company size is, the greater possibility of idle funds will be; idle funds can lead to company"s poor performance [2]. Of course, the debt paying ability of companies with idle funds is stronger than companies without idle funds. On that basis, the following hypotheses are proposed:

Hypothesis 1: Idle funds are related to the holding of free cash flow. The more free cash flow exists, the more idle funds will be.

Hypothesis 2: Institutional investors can restrict idle funds. But the impact is relatively low.

Hypothesis 3: Different institutional investors play different roles on idle funds.

\section{Research Design}

Data sources and sample selection. In this paper, data of A-share listed companies from annual reports of Shanghai and Shenzhen Stock Exchange from the year 2009 to 2014 is collected. Then, data of raised idle funds in annual reports according to different years is grouped and analyzed. Selection standards are as follows. (1) Companies which have experienced PT and ST are excluded. (2) Financial data and companies with data loss are excluded. Finally, we select 1021 records of sample firms. Among them, 318 companies are selected in 2009; 241 companies are selected in 2010; 
157 companies are selected in 2011; 123 companies are selected in 2012; 88 companies are selected in 2013; 94 companies are selected in 2014. Data of institutional investors" shares comes from the Wind database; relevant financial data comes from the GuoTai"An database. Spass20.0 statistical software is used to carry out the empirical test.

\section{Setting and interpretation of variables.}

Table 1 Setting and Meaning of variables

\begin{tabular}{|c|c|c|c|}
\hline variables & Variable names & code & Meaning of variables \\
\hline $\begin{array}{l}\text { explained } \\
\text { variables }\end{array}$ & Idle funds ratio & IDL & $\begin{array}{l}\text { idle funds / assets } \\
\text { Referring the reports of funds usage in annual } \\
\text { reports, data of companies" total assets at year } \\
\text { end is divided by the amount of money } \\
\text { deposited in special bank accounts. }\end{array}$ \\
\hline \multirow{8}{*}{$\begin{array}{c}\text { explanatory } \\
\text { variables }\end{array}$} & $\begin{array}{l}\text { Shareholding ratio of } \\
\text { institutional investors }\end{array}$ & Insist & $\begin{array}{l}\text { institutional ownership / total number of liquid } \\
\text { stocks }\end{array}$ \\
\hline & free cash flow & Fcf & $\begin{array}{l}\text { [(cash flows generated from operating activities } \\
\text { - repayments of distributing dividends and } \\
\text { profits, or paying interests + cash received from } \\
\text { issuing bonds + cash received from borrowings } \\
\text { - repayments of borrowings)] - capital } \\
\text { expenditure + cash equivalent at end of the } \\
\text { period] / total assets at end of the period }\end{array}$ \\
\hline & $\begin{array}{c}\text { Tobin Q (growth } \\
\text { opportunity) }\end{array}$ & Tobin-q & growth opportunity of the company \\
\hline & $\begin{array}{l}\text { rate of return on total } \\
\text { assets }\end{array}$ & Roa & net margin / average balance of total assets \\
\hline & velocity of liquid assets & Rat & $\begin{array}{l}\text { main business income/ the average total } \\
\text { amount of liquid assets }\end{array}$ \\
\hline & liquidity ratio & $\mathrm{Rr}$ & the ratio of liquid assets to liquid liabilities \\
\hline & dividends per share & Dps & $\begin{array}{l}\text { the ratio of total amount of dividends to the } \\
\text { number of circulating shares }\end{array}$ \\
\hline & rate of dividend payout & Divid & $\begin{array}{l}\text { the ratio of cash dividends to total income of a } \\
\text { common share }\end{array}$ \\
\hline \multirow{3}{*}{$\begin{array}{l}\text { Control } \\
\text { variables }\end{array}$} & firm size & Size & $\begin{array}{l}\text { the size of company, the natural logarithm of } \\
\text { total assets at year end }\end{array}$ \\
\hline & asset-liability ratio & Level & $\begin{array}{l}\text { liability/asset, } \\
\text { represent the level of liabilities }\end{array}$ \\
\hline & $\begin{array}{c}\text { share ratio of the largest } \\
\text { shareholder }\end{array}$ & Top1 & $\begin{array}{l}\text { the largest shareholder in the ten largest } \\
\text { shareholders }\end{array}$ \\
\hline
\end{tabular}




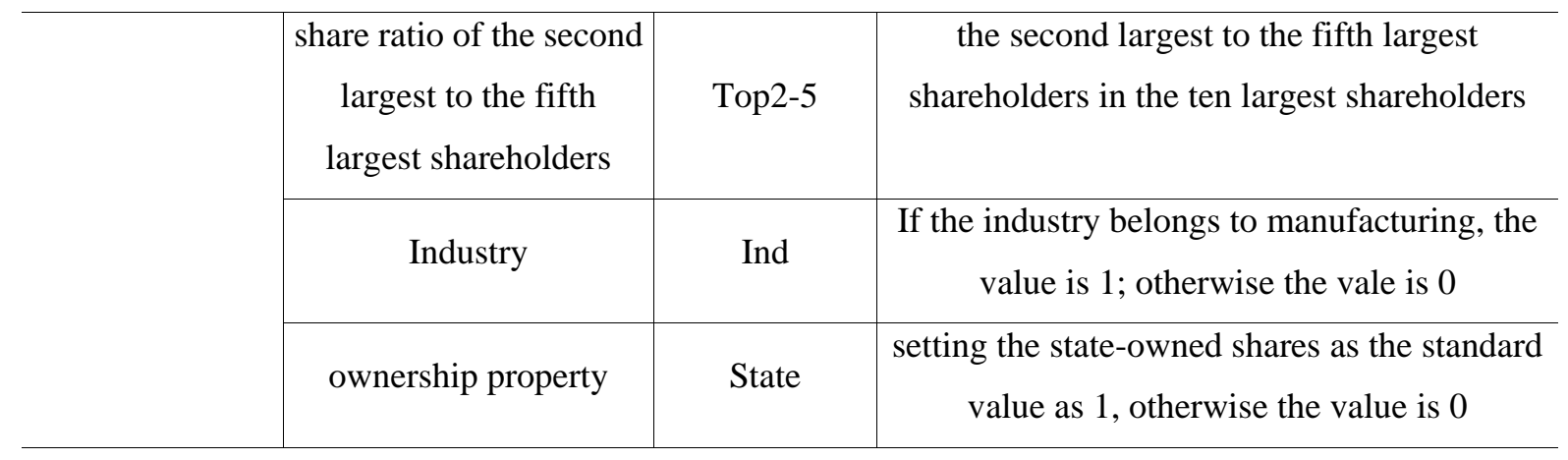

\section{Model construction.}

Model 1, relationship between free cash flow and idle funds

$$
\text { ratio }^{\text {IDL }}=\beta_{0}+\beta_{1} \text { Fcf }+\beta_{2} \text { Level }+\beta_{3} \text { Size }+\beta_{4} \text { Cash }+\beta_{5} \text { Rr }+\beta_{6} \text { Tobin }-q+\beta_{7} \text { Rat }+\varepsilon
$$

Model 2, relationship between institutional investors and funds idle

$$
\begin{aligned}
& \text { IDL }=\beta_{0}+\beta_{1} \text { Insist }+\beta_{2} \text { Level }+\beta_{3} \text { Size }+\beta_{4} \text { Cash }+\beta_{5} \text { Rr }+\beta_{6} \text { Tobin }-\mathrm{q} \\
& +\beta_{7} \text { Rat }+\beta_{8} \text { Top } 1++\beta_{9} \text { Top } 2-5++\beta_{10} \text { State }++\beta_{11} \text { Divid } \\
& \text { rate } \\
& +\sum \text { industry }+\varepsilon
\end{aligned}
$$

Model 3, the relationship between capital idle rate and enterprise performance

$$
\text { ROA }=\beta_{0}+\beta_{1} \text { Idl }+\beta_{2} \text { Level }+\beta_{3} \text { Size }+\beta_{4} \text { Rat }+\beta_{5} \text { Tobin }-q+\sum \text { industry }+\varepsilon
$$

Model 4, the relationship between the various types of institutional investors and the idle rate of funds

$$
\begin{gathered}
\text { IDL }=\beta_{0}+\beta_{1} \text { NInsist }+\beta_{2} \text { Level }+\beta_{3} \text { Size }+\beta_{4} \text { Cash }+\beta_{5} \text { Tobin }-q+\beta_{6} \text { Rat }+\beta_{7} \text { Divid } \\
+\sum \text { industry }+\varepsilon
\end{gathered}
$$

\section{Empirical tests and analyses.}

Descriptive analyses

Table 2 Descriptive Statistics

\begin{tabular}{c|c|c|c|c|c}
\hline Variables & $\mathrm{N}$ & mean & Maximum & Minimum & $\begin{array}{c}\text { standard } \\
\text { deviation }\end{array}$ \\
\hline idle funds ratio & 1021 & 0.2688 & 1.0300 & 0.0000 & 0.2521 \\
\hline $\begin{array}{c}\text { shareholding ratio of } \\
\text { institutional investors }\end{array}$ & 1021 & 38.3900 & 114.2182 & 0.0000 & 24.4847 \\
\hline free cash flow & 1021 & 0.1944 & 1.0835 & -0.6643 & 0.1749 \\
\hline firm size & 1021 & 21.9740 & 28.1356 & 19.2426 & 1.2983 \\
\hline asset-liability ratio & 1021 & 0.4099 & 0.9730 & 0.0000 & 0.1929 \\
\hline $\begin{array}{c}\text { share ratio of the largest } \\
\text { shareholder }\end{array}$ & 1021 & 36.0820 & 86.2000 & 4.4900 & 14.7110 \\
\hline $\begin{array}{c}\text { share ratio of the second } \\
\text { largest to the fifth largest } \\
\text { shareholders }\end{array}$ & 1021 & 15.6450 & 54.1000 & 0.8000 & 10.6666 \\
\hline
\end{tabular}




\begin{tabular}{c|c|c|c|c|c}
\hline $\begin{array}{c}\text { Tobin Q (growth } \\
\text { opportunity) }\end{array}$ & 1016 & 2.1301 & 14.7157 & 0.0000 & 1.6520 \\
\hline $\begin{array}{c}\text { rate of return on total } \\
\text { assets }\end{array}$ & 1021 & 0.0726 & 0.5475 & -5.5020 & 0.1916 \\
\hline velocity of liquid assets & 1021 & 1.2056 & 13.3465 & 0.0000 & 1.0266 \\
\hline liquidity ratio & 1021 & 4.1201 & 1757.4082 & 0.0000 & 55.0308 \\
\hline dividends per share & 1021 & 0.1022 & 1.0000 & 0.0000 & 0.1249 \\
\hline rate of dividend payout & 1021 & 0.3068 & 27.8990 & -2.7549 & 1.0982 \\
\hline cash holding ratio & 1021 & 0.2028 & 0.9309 & 0.0000 & 0.1404 \\
\hline Effective N (state list) & 1016 & & & & \\
\hline
\end{tabular}

Regression Analysis. Model 1 shows the relationship between free cash flow and idle funds. The results show that, the growth opportunities of Tobin $\mathrm{Q}$ value, velocity of liquid asset, the size of company and cash holding ratio are negatively correlated with idle funds; the relationships are significant when $\mathrm{P}$ less than 0.05 . If the company has good growth opportunities and large number of investment opportunities, the funds raised by the company will be in short supply. The circulation of capital funds will be fast, and the idle funds rate will decline. Companies with more idle funds tend to have stronger debt paying ability. The cash holding ratio and free cash flow are positively correlated with idle funds, and the relationships are very significant. Free cash flow is also an important part of idle funds. When the value of $\mathrm{P}$ is 0.069 which is less than 0.1 , the relationship is significant. It indicates that if a company has a lot of free cash flow, it will probably have more idle funds than companies with little cash flow.

Table 3 Regression Coefficients A of Model 1

\begin{tabular}{|c|c|c|c|c|c|c|}
\hline \multirow{2}{*}{\multicolumn{2}{|c|}{ model }} & \multicolumn{2}{|c|}{$\begin{array}{c}\text { Non-standard } \\
\text { coefficient }\end{array}$} & \multirow{3}{*}{$\begin{array}{c}\text { Standard } \\
\text { coefficient } \\
\text { trial version }\end{array}$} & \multirow{3}{*}{\begin{tabular}{c|}
$\mathrm{t}$ \\
3.891
\end{tabular}} & \multirow{3}{*}{$\begin{array}{l}\text { Sig. } \\
.000\end{array}$} \\
\hline & & \multirow{2}{*}{\begin{tabular}{|l} 
B \\
.631
\end{tabular}} & \multirow{2}{*}{$\begin{array}{l}\text { standard } \\
\text { error } \\
.162\end{array}$} & & & \\
\hline 1 & constant & & & & & \\
\hline & free cash flow & .054 & .061 & .037 & .2551 & .069 \\
\hline & Tobin Q & -.013 & .006 & -.084 & -2.224 & .026 \\
\hline & $\begin{array}{l}\text { velocity of liquid } \\
\text { assets }\end{array}$ & -.023 & .008 & -.094 & -3.041 & .002 \\
\hline & asset-liability ratio & -.078 & .050 & -.060 & -1.557 & .120 \\
\hline & firm size & -.017 & .007 & -.086 & -2.305 & .021 \\
\hline & cash holding ratio & .513 & .080 & .284 & 6.451 & .000 \\
\hline & liquidity ratio & $5.551 \mathrm{E}-6$ & .000 & .001 & .040 & .968 \\
\hline & $\mathrm{R}$ & & & & & $.326^{\mathrm{a}}$ \\
\hline & square of $\mathrm{R}$ & & & & & .107 \\
\hline & adjust the square of $\mathrm{R}$ & & & & & .100 \\
\hline & df1 & & & & & 1008 \\
\hline & Sig. F alter & & & & & 0.000 \\
\hline
\end{tabular}

A.Dependent variable: rate of idle funds. 
Model 2 shows the relationship between institutional investors and idle funds. From the verification results, it can be concluded that institutional investors and idle funds are negatively correlated. The value of $\mathrm{P}$ is 0.000 which is less than 0.05 , means that relationship is significant. Institutional investors can urge the company to actively use raised funds, to improve the use efficiency of funds, and to reduce idle funds. But the coefficient B is -0.002 , it represents that if institutional investors change by 1 , the idle funds will reduce 0.002 . Institutional investors" attention on idle funds is not enough. There is no significant correlation between large shareholders and company"s idle funds, which indicates that shareholders do not pay enough attention to these funds. They mainly care about the investments of company"s idle funds in the future and the expected returns.

Table 4 Regression Coefficients A of Model 2

\begin{tabular}{|c|c|c|c|c|c|c|}
\hline \multirow{2}{*}{\multicolumn{2}{|c|}{ Model }} & \multicolumn{2}{|c|}{ Non-standard coefficient } & \multirow{2}{*}{$\begin{array}{c}\text { Standard } \\
\text { coefficient } \\
\text { trial version }\end{array}$} & \multirow[b]{2}{*}{$\mathrm{t}$} & \multirow[b]{2}{*}{ Sig. } \\
\hline & & B & standard error & & & \\
\hline \multirow[t]{13}{*}{2} & constant & .356 & .171 & & 2.079 & .038 \\
\hline & $\begin{array}{l}\text { institutional } \\
\text { investor }\end{array}$ & -.002 & .000 & -.190 & -5.913 & .000 \\
\hline & Tobin Q value A & -.010 & .006 & -.064 & -1.665 & .096 \\
\hline & $\begin{array}{l}\text { velocity of liquid } \\
\text { assets A }\end{array}$ & -.020 & .008 & -.082 & -2.680 & .007 \\
\hline & asset-liability ratio & -.063 & .050 & -.048 & -1.268 & .205 \\
\hline & company size & -.004 & .008 & -.020 & -.496 & .620 \\
\hline & cash holding ratio & .455 & .060 & .251 & 7.521 & .000 \\
\hline & liquidity ratio & $3.550 \mathrm{E}-6$ & .000 & .001 & .026 & .979 \\
\hline & $\begin{array}{l}\text { the largest } \\
\text { shareholder }\end{array}$ & .001 & .001 & .060 & 1.809 & .071 \\
\hline & ownership property & -.029 & .018 & -.050 & -1.615 & .107 \\
\hline & $\begin{array}{l}\text { the } 2^{\text {nd }}-5^{\text {th }} \text { largest } \\
\text { shareholder }\end{array}$ & .001 & .001 & .036 & 1.116 & .265 \\
\hline & industry & .016 & .017 & .029 & .956 & .339 \\
\hline & $\begin{array}{l}\text { dividend payout } \\
\text { ratio }\end{array}$ & -.008 & .007 & -.037 & -1.243 & .214 \\
\hline & $\mathrm{R}$ & & & & & $.374^{\mathrm{a}}$ \\
\hline & the square of $\mathrm{R}$ & & & & & .140 \\
\hline & $\begin{array}{l}\text { adjust the square of } \\
\mathrm{R}\end{array}$ & & & & & .129 \\
\hline & $\mathrm{df}$ & & & & & 1003 \\
\hline & Sig. F alter & & & & & 0.000 \\
\hline
\end{tabular}

A.Dependent variable: rate of idle funds.

Model 3 shows the relationship between idle funds and enterprise performance. Table 5 shows that idle funds and the performance of company are negatively correlated, but the correlation is not significant. It represents that idle funds just reduce the normal service efficiency of this part of funds. 
Idle funds which are used for financial management and purchasing financial products can also get short-term gains. Overall, idle funds and enterprise performance have little relationship. Of course, if the company gives full play to this part of idle funds, the performance of company will be greatly promoted.

Table 5 Regression Coefficients A of Model 3

\begin{tabular}{|c|c|c|c|c|c|c|}
\hline \multirow{2}{*}{\multicolumn{2}{|c|}{ Model }} & \multicolumn{2}{|c|}{$\begin{array}{c}\text { Non-standard } \\
\text { coefficient }\end{array}$} & \multirow{3}{*}{$\begin{array}{l}\text { Standard } \\
\text { coefficient } \\
\text { trial version }\end{array}$} & \multirow{3}{*}{$\begin{array}{l}\mathrm{t} \\
-5.707\end{array}$} & \multirow{3}{*}{$\begin{array}{l}\text { Sig. } \\
.000\end{array}$} \\
\hline & & \multirow{2}{*}{$\begin{array}{l}\text { B } \\
-.191\end{array}$} & \multirow{2}{*}{$\begin{array}{r}\begin{array}{l}\text { standard } \\
\text { error }\end{array} \\
.033\end{array}$} & & & \\
\hline 3 & constant & & & & & \\
\hline & vacancy rate & -.001 & .006 & -.004 & -.144 & .886 \\
\hline & industry & .004 & .003 & .038 & 1.306 & .192 \\
\hline & asset-liability ratio & -.065 & .010 & -.233 & -6.661 & .000 \\
\hline & company size & .010 & .001 & .249 & 7.012 & .000 \\
\hline & Tobin Q value & .013 & .001 & .400 & 11.385 & .000 \\
\hline & $\begin{array}{l}\text { velocity of liquid } \\
\text { assets A }\end{array}$ & .004 & .002 & .072 & 2.469 & .014 \\
\hline & $\mathrm{R}$ & & & & & $.453^{\mathrm{a}}$ \\
\hline & square of $\mathrm{R}$ & & & & & .205 \\
\hline & adjust the square of $\mathrm{R}$ & & & & & .200 \\
\hline & df & & & & & 1009 \\
\hline & Sig. $\mathrm{F}$ alter & & & & & .000 \\
\hline
\end{tabular}

A.Dependent variable: rate of return on total assets.

Model 4 shows the relationship between the various types of institutional investors and idle funds. Table 6 shows that funds, insurance companies, social security funds and QFII are negatively correlated with idle funds. The correlation between funds and idle funds is significant, but the coefficient is -0.001 , which means the influence is weak. The broker and idle funds are positively correlated, but the correlation is not significant. It shows that most institutional investors can play a role in the supervision of the companies" idle funds, but that impact is not enough. First, the proportion of institutional ownership is low. Second, institutional investors tacitly approve the company to keep certain free cash flow for the purpose of risk prevention.

Table 6 Regression Coefficients A of Model 4

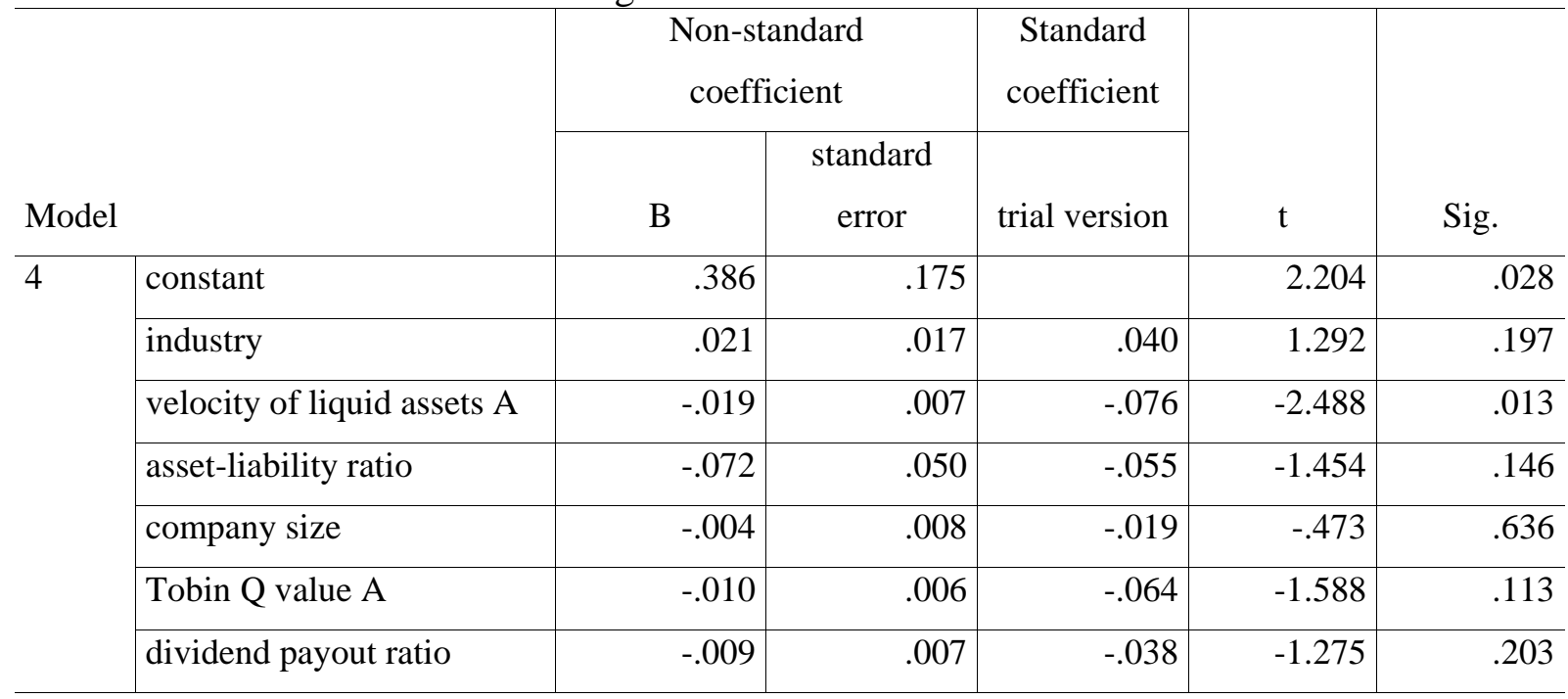




\begin{tabular}{|c|c|c|c|c|c|}
\hline cash holding ratio & .471 & .060 & .260 & 7.836 & .000 \\
\hline ratio of funds in A-shares & -.001 & .001 & -.071 & -1.913 & .056 \\
\hline ratio of brokers in A-shares & .006 & .012 & .017 & .530 & .597 \\
\hline $\begin{array}{l}\text { ratio of insurance } \\
\text { companies in A-shares }\end{array}$ & -.008 & .006 & -.043 & -1.381 & .168 \\
\hline $\begin{array}{l}\text { ratio of social security } \\
\text { funds in A-shares }\end{array}$ & -.002 & .007 & -.010 & -.320 & .749 \\
\hline ratio of QFII in A-shares & -.012 & .013 & -.028 & -.915 & .360 \\
\hline $\mathrm{R}$ & & & & & $.368^{\mathrm{a}}$ \\
\hline square of $\mathrm{R}$ & & & & & .135 \\
\hline adjust the square of $\mathrm{R}$ & & & & & .124 \\
\hline $\mathrm{df}$ & & & & & 1015 \\
\hline $\mathrm{F}$ & & & & & 12.080 \\
\hline Sig. & & & & & $.000^{\mathrm{a}}$ \\
\hline
\end{tabular}

A. Dependent variable: rate of idle funds.

\section{Conclusions}

Idle funds are commonly seen in listed companies. These companies use various earnings management means, like falsely increasing the corporations" benefits, dressing up company"s economic performance and exaggerating the expected returns of investment projects, to raise money from capital markets. However, due to difficulties in investment opportunities, the prospects of these investment projects are not bright. Companies cannot quickly put these raised funds into project construction; a large amount of money has to be deposited into banks and become idle funds. Idle funds are often used inefficiently for purchasing other financial products, or being treated as supplement of companies" liquidity.

This paper empirically studies the relationships between idle funds and free cash flow, corporate performance and institutional investors. The results show that free cash flow and idle funds are positively correlated. The more free cash flow exists, the greater amount of idle funds will be. Idle funds do not have weak influence on enterprise performance. Institutional investors have large ratios of shareholding and professional advantages, so they can play a role in the supervision of funds-raising progress and the management of idle funds. Idle funds only bring temporary investment opportunity costs; they do not affect the performance of company. Thus, institutional investors show their acquiescence, and allow the company to retain some idle funds to keep capital turnover. Due to the differences of shareholding ratios, investment preferences and interest relationships with the company, different institutional investors play different roles in idle funds. Among these institutional investors, funds, insurance companies, social security funds and QFII are negatively related with idle funds. It shows that most institutional investors can supervise the management of idle funds, but the supervision is not efficient. The increase of institutional investors" shareholding ratios and the improvement of their supervision abilities are needed in the future.

\section{Acknowledgement}

This paper is one of the outcomes of the project named Measurement Research on the Employees" Incomes and Capital Returns of Financial Equity in Listed Companies which is supported by National Social Science Foundation of China (Project No.: 13BJY015); it also one of the outcomes of the project named Research on the Performance Changes of Listed Companies in China Based on Free 
Cash Flow which is supported by National Natural Science Foundation of China (Project No.: 70672013).

\section{References}

[1] Q. Liu, M.P. Lu, X.Q. Xun, C.Y. He, Research on regulations and changing the purposes of raised funds, J. Securities Market Herald. 1 (2002) 35-40.

[2] J. Liu, Z.M. Guo, L. Li, An Empirical Study on idle raised funds and performance of listed companies, J. Inquiry Into Economic Issues. 4 (2008) 158-163. 